\title{
MODEL SISTEM MEDIA KONTEMPORER
}

Memahami system media modern tidak bisa dipisahkan dengan pemahaman tentang system sosial masyarakat modern. Bagan sederhana pemahaman masyarakat modern adalah sebagai berikut:

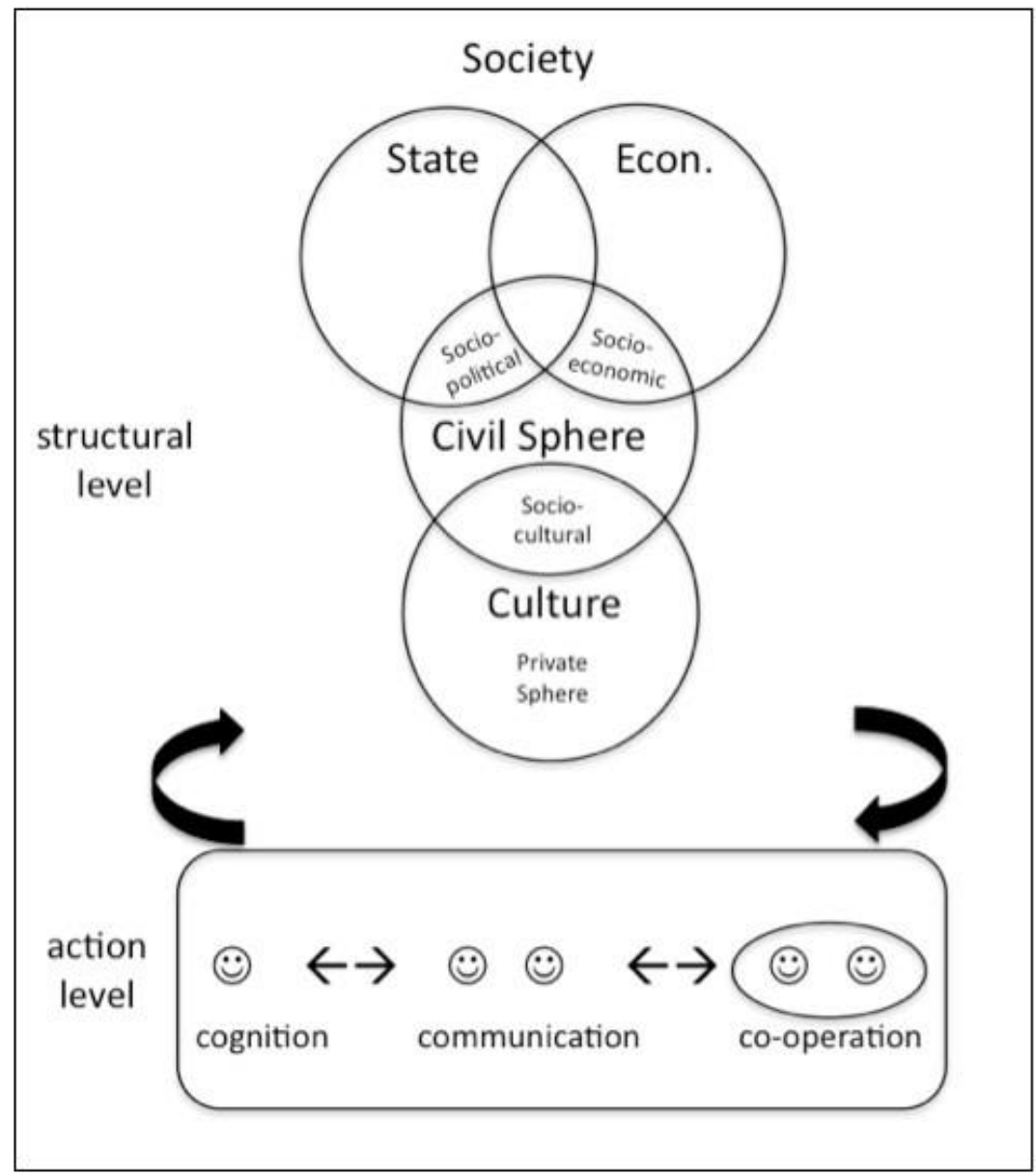

Gambar di atas adalah visualisasi model masyarakat modern. Model ini didasarkan pada perspektif teori sosial bahwa hubungan antara struktur dan aktor adalah dialektis. Kedua level di atas (level aksi dan level structural) adalah level yang terus menerus membuat satu sama lain (untuk solusi dialektis dari masalah struktur-lembaga dalam teori sosial, lihat: Archer 1995, Bhaskar 1993, Bourdieu 1986 , Fuchs 2003a, 2003b, Giddens 1984). Habermas (1987, 320) menjelaskan peran sosial adalah hal yang konstitutif bagi masyarakat modern: karyawan, konsumen, klien, warga. peran lain. Jadi apa yang konstitutif bagi masyarakat modern tidak hanya pemisahan ruang dan peran, tetapi juga penciptaan struktur kekuasaan, di mana peran 
yang dibentuk oleh dan terhubung ke hubungan kekuasaan (sebagai misalnya majikan-karyawan, negara birokrasi-warga, warga bangsa negara-imigran, manager-asisten, peran gender yang dominan - peran gender terpinggirkan). Kekuasaan dalam konteks ini adalah disposisi pelaku yang diartikan sebagai hal yang memungkinkan mereka untuk mengontrol struktur, proses pengaruh dan keputusan demi kepentingan mereka sendiri. Dalam ekonomi modern, manusia bertindak sebagai pemilik modal atau pekerja. Dalam sistem politik modern, mereka bertindak sebagai politisi atau warga negara. Dalam sistem budaya modern, mereka memiliki peran teman, kekasih, anggota keluarga dan konsumen. Masyarakat modern tidak hanya didasarkan pada diferensiasi alam sosial, tetapi juga diferensiasi peran sosial manusia mengambil di alam ini. Di ranah publik, manusia tidak bertindak dalam isolasi sosial, tapi kesamaan sosial. Untuk Hannah Arendt, ruang publik karena itu "dunia umum" bahwa "mengumpulkan kita bersama-sama dan belum mencegah kita jatuh satu sama lain" (Arendt 1958, 52). Di ruang publik, manusia mengatur kepentingan di sekitar tertentu sebagai kelompok sosial. Sebagai kelompok mereka mengambil peran sosial-ekonomi, sosial-politik dan sosial-budaya.

Bagaimana system media dipahami dalam konteks dan konstelasi di atas. Hal itu bisa memperhitungkan system dialektika berkelanjutan dalam system masyarakat modern sekarang. Seperti yang tergambar dalam bagan berikut:

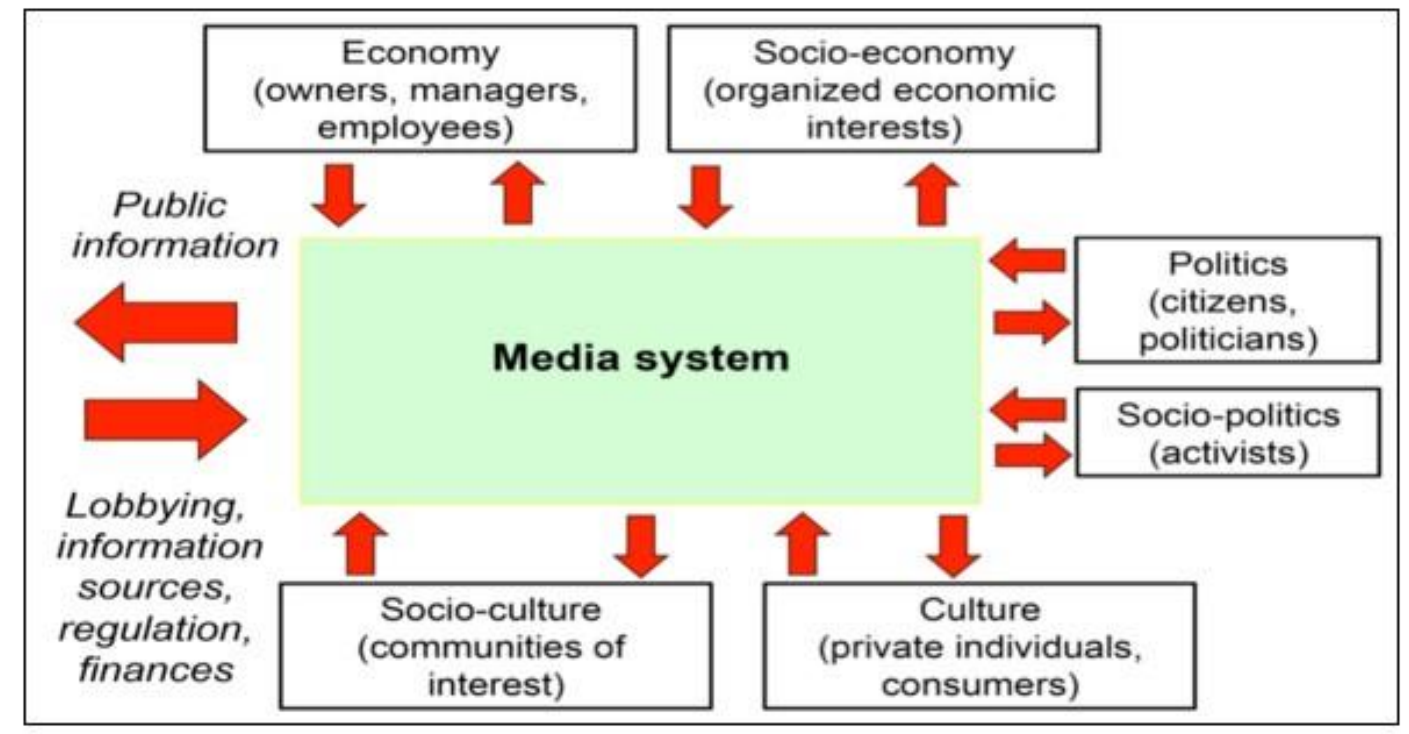

Habermas menyatakan (1984, 1987), media adalah entitas yang memungkinkan hubungan sosial. Ia membedakan antara kontrol media secara ekonomi dan politik di satu sisi 
dan tindakan komunikasi tak termediasikan di sisi lain. Niklas Luhmann (1995) berbeda dengan Habermas berpendapat bahwa semua sistem sosial adalah sistem komunikasi dan mengatur tindakan komunikasi di sekitar media tertentu. Komunikasi adalah hubungan sosial, di mana manusia berinteraksi saling dengan media simbol dan dengan demikian menciptakan makna satu sama lain dan dunia. Ini adalah fitur konstitutif masyarakat dan semua sistem sosial.

Komunikasi membutuhkan dan tidak mungkin tanpa Media: media penyimpanan (teknologi informasi) seperti kertas, kaset, roll film, komputer hard disk, DVD, ruang web; Media transportasi (teknologi komunikasi) seperti telepon, televisi, radio, e-mail; dan media kolaboratif (teknologi kerjasama) seperti wiki dan komunitas online.

Sedangkan properti (seperti uang dan komoditas lainnya) dan kekuasaan pasti bisa dilihat sebagai media hubungan sosial, fitur tertentu dari sistem media. Komunikasi adalah komunikasi konten yang dibuat oleh manusia untuk disimpan, ditafsirkan dan ditafsirkan ulang. Dalam masyarakat modern, sistem budaya tidak terisolasi, tetapi budaya dimediasi oleh kapital dalam industri budaya dan kekuasaan dalam komunikasi politik. Sistem budaya memiliki sistem ekonomi dan politik sendiri.

Gambar 1 telah menunjukkan bahwa masyarakat sipil dan ruang publik adalah inter-relasi yang menghubungkan budaya, ekonomi dan politik melalui sosial-budaya, sosial-politik dan bidang sosial-ekonomi. Semua media informasi beredar ide-ide di depan umum untuk berbagai orang. Media dengan informasi sebagai pribadi dalam peran budaya mereka, sebagai anggota masyarakat dari kepentingan di bidang sosial budaya, sebagai warga negara atau politisi di bidang politik, sebagai aktivis di bidang sosial-politik, sebagai pemilik, pengelola atau karyawan dalam sistem ekonomi, dan sebagai anggota dari kelompok kepentingan ekonomi dalam ranah sosial-ekonomi. Konten yang disediakan oleh media, manusia menciptakan, kembali membuat dan membedakan makna dunia dalam berbagai peran sosial.

Gambar itu juga menunjukkan interaksi dari sistem media yang dengan bagian lain dari masyarakat modern. Media membuat informasi publik (berita, hiburan, user-generated content dll) yang dihadapi manusia dalam berbagai peran sosial, di mana mereka membuat makna dunia berdasarkan informasi ini. Dalam rangka untuk menciptakan konten budaya, pekerja di sistem media mengandalkan sampai batas tertentu pada manusia di berbagai peran sosial sebagai sumber informasi. Sumber informasi ini cenderung didistribusikan secara asimetris dengan politisi, pemerintah, pihak, selebriti, ahli, perusahaan dan manajer memainkan peran signifikan 
lebih penting daripada warga sehari-hari. Sistem media juga membutuhkan masukan dari sistem ekonomi (pembiayaan dalam bentuk pinjaman, uang yang dibayarkan untuk konten atau pemirsa, subsidi, sumbangan) dan sistem politik (hukum, regulasi). 